\title{
Limitation of Geosynthetics Usage on Road Subgrade
}

\author{
K. Pospisil* \& P. Zednik \\ Department of Infrastructure, CDV - Transport Research Centre, Brno, Czech Republic \\ *Corresponding author: karel.pospisil@cdv.cz
}

\begin{abstract}
There are several ways of geosynthetics functionality. Well-known mechanisms are functions of separating, filtrating, protecting and slope reinforcing. There are several publications describing the influence of geosynthetics on increasing the soft-soil bearing capacity and their positive role on final subbase deformation. However, this geosynthetics functionality has not been explained satisfactorily in detail yet. The research presented here deals with clarifying the possible geosynthetics functionality. Six kinds of geosynthetics of world renowned producers were selected for testing. The measurement was carried out in the Geotechnical Laboratory Testing Field (GLTF), which is a facility constructed for fullscale geotechnical measurements. The results of static plate tests show that the contribution of the geosynthetics to the bearing capacity increase is very limited. A significant increase appears only in the case of a very low bearing capacity subgrade covered by a $20 \mathrm{~cm}$ thick subbase layer reinforced by some geosynthetics. After the static part of the experiment the GLTF was equipped with a cyclic loader to simulate real traffic loading and tests for the evaluation of possible bearing capacity increase and deformation decrease due to geosynthetics usage were repeated.
\end{abstract}

KEY WORDS: Subgrade, pavement, geosynthetics, bearing capacity, deformation

\section{INTRODUCTION}

Although the reinforcing functionality of geosynthetics is described and used in connection with slopes reinforcement, there are many practical examples of geosynthetics usage as a reinforcing element of pavement, subbase or subgrade layers. At the same time, this application is put to laboratory, full-scale or real construction tests. The results and outputs of the tests are highly incomparable because of non-uniform test methodologies and some of them being purpose-built by geosynthetics producers. Maybe this could be the reason why the EU standards do not include this way of geosynthetics application.

Principles of the evaluation of the geosynthetics impact on bearing capacity are based either on the static loading of reinforced layers (Blumme et al., 2001), expressed by the relationship between loading and deformation (elastic modulus, deformation modulus or k-modulus, conversion to or from CBR), or on cyclic/dynamic loading done either by a circular plate (Perkins, 2002) or by repeated wheel running (Watn et al., 1996 and Jenner et al., 2002), evaluated by a time-based deformation (number of loading cycles or wheel running vs. layer deformation). Based on the time-based deformation the back-calculation methods were formulated (e.g., van Niekerk and van Gurp, 2002).

It is essential for each experiment to take into account the following parameters: material properties (soil, aggregate, geosynthetics, etc.), test condition (subsoil bearing capacity, layers 
compaction rate, etc.), geometrical parameters (dimensions, model similarity) and test arrangement (speed, range and frequency of loading, shape of the loading wave, etc.).

Unfortunately, many published papers are missing the mentioned parameters. This is a very serious cause for the incomparability of the published results. The tests are often based on "national" test methods and are valid only when using specific geosynthetics (e.g., Beckmann and Ruppert, 1994, Saathoff and Horstmann, 1999). There is a comprehensive review of sophisticated tests containing available tests parameters (Berg, 2000).

\section{ENVIRONMENT, PARAMETERS AND RESULTS OF STATIC TESTS}

The tests were carried out in the Geotechnical Laboratory Testing Field (GLTF). The GLTF is a facility available for full-scale geotechnical tests, which allows for the measuring in a laboratory of some geotechnical quantities that are otherwise usually measured in the field (e.g., plate test, dynamic loading test, penetration test, etc.) on various soils and soil layers for different compaction rate and for different water regimes.

The GLTF, see Figure 1, is about 10 meters long and consists of a concrete pit split by removable dividers into separated measuring (testing) spaces and a watering/dewatering drain channel, also separated by removable dividers. There is a drain layer placed on the bottom of each measuring space covered with a grate with a drainage geotextile (filter). Both the concrete pit and the drain channel are interconnected at their bottoms. A moveable frame can be slid in the longitudinal direction along a guide-way (rails) fastened on the top of the pit. The moveable frame serves for mounting or supporting the measuring equipment (plate test, CBR in situ test equipment, etc.) and can be blocked in both horizontal and vertical directions during testing.

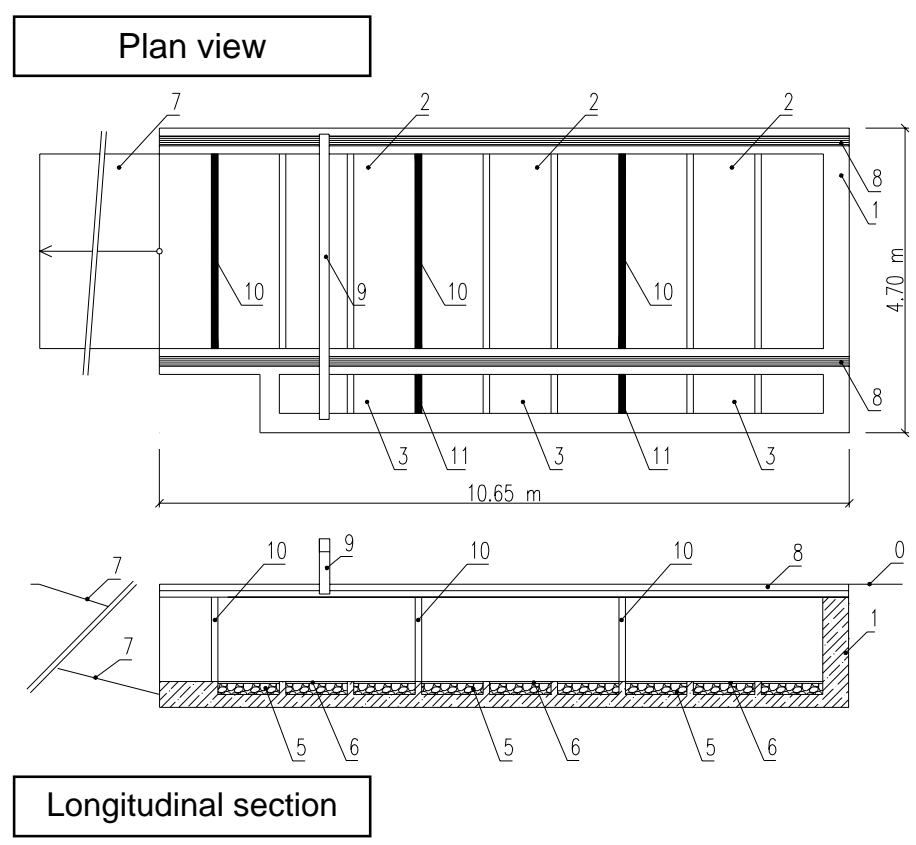

\section{Cross section}

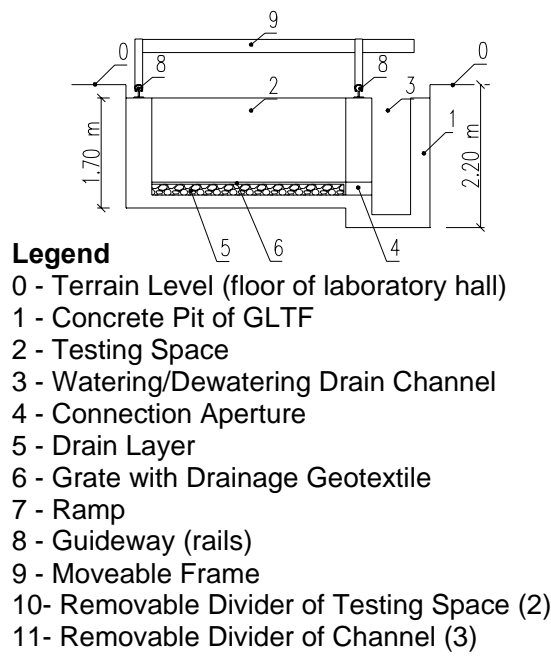

Figure 1: Design of the Geotechnical Laboratory Testing Field (GLTF)

\subsection{Tests arrangement}

As indicated above, the tests were carried out in the GLTF that had been divided into three testing spaces of a same size $(3 \mathrm{~m} \times 3 \mathrm{~m})$. There were five series of tests. One series means 
two geosynthetics measuring in one step - one by one in each of two testing spaces (laid on subgrade), and in one testing space that was kept without geosynthetics for a comparison. The first and the second series of testing were done on a subgrade with modulus of deformation about $\mathrm{E}_{\mathrm{v} 2}=5 \mathrm{MPa}$, and the third, fourth and fifth series were carried out on a subgrade with modulus of deformation about $E_{\mathrm{v} 2}=15 \mathrm{MPa}$. The subsoil was spread and compacted into GLTF layer by layer up to the final thickness of $70 \mathrm{~cm}$. The material of the subsoil layers was the same for both $5 \mathrm{MPa}$ and $15 \mathrm{MPa}$ subgrade moduli (different bearing capacities were achieved by the moisture content of the subsoil).

The individual series of testing varied in types of geosynthetics used and subbase layers thicknesses laid on geosynthetics (or directly on the subgrade in case of the geosynthetics-free testing space). The first series had the thickness of the first subbase layer $20 \mathrm{~cm}$ and the second subbase layer $20 \mathrm{~cm}$ (i.e., a $40 \mathrm{~cm}$ subbase layer in total). The second series of testing had the thicknesses of the subbase layers $15 \mathrm{~cm}+15 \mathrm{~cm}=30 \mathrm{~cm}$ in total. The third, fourth and fifth series had the same thicknesses of subbase layers $20 \mathrm{~cm}+10 \mathrm{~cm}=30 \mathrm{~cm}$ in total. An example of the test arrangement is shown in Figure 2. Parameters of each of the five series of testing are concentrated in Table 2 .

Deformation characteristics as bearing capacity view were obtain from the static plate test according to German Standard DIN 18134 and were measured on subgrade and on the first and on the second subbase layers.

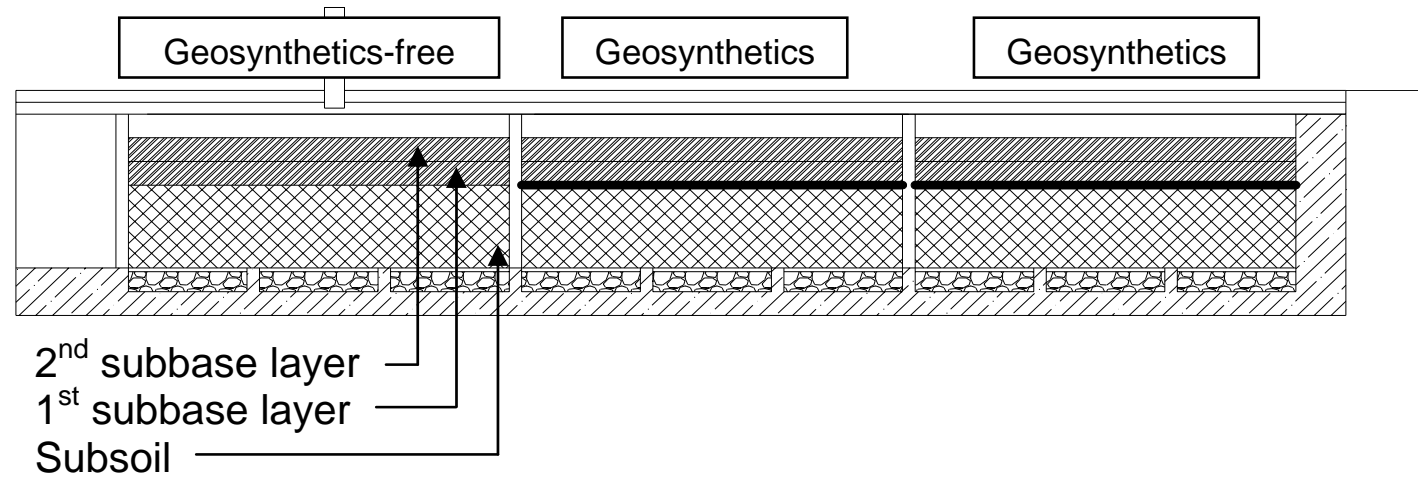

\section{Figure 2: The test arrangement in GLTF}

\subsection{Material parameters}

Used subsoil:

- Weak subsoil was simulated by clayey soil with high plasticity

- Grading:

$$
\begin{array}{llll}
\mathrm{o} & \mathrm{g}(2.0-60.0) & \ldots & 0 \%, \\
\mathrm{o} & \mathrm{s}(0.063-2.0) \ldots 5 \%, \\
\mathrm{o} & \mathrm{f}(0.0-0.063) \ldots & 55 \%=\mathrm{m}(0.002-0.06) \ldots 55 \%+\mathrm{c}(0.0-0.06) \ldots 40 \% \\
\end{array}
$$

- Moisture content: $\mathrm{w}_{\text {nat }}=28.9 \%, \mathrm{w}_{\mathrm{opt}, \mathrm{PS}}=21.5 \%$

- Plasticity: $\mathrm{w}_{\mathrm{L}}=51 \%, \mathrm{w}_{\mathrm{P}}=17 \%, \mathrm{I}_{\mathrm{P}}=34 \%, \mathrm{I}_{\mathrm{C}}=0.64$

Used material for subbase layers:

- Unbound gravel material (fraction 0 - $32 \mathrm{~mm}$ )

- Grading:

$$
\begin{array}{lllll}
\mathrm{o} & \mathrm{g}(2.0-60.0) & \ldots & 70 \% \text {, } \\
\mathrm{o} & \mathrm{s}(0.063-2.0) & \ldots & 27 \%, \\
\mathrm{o} & \mathrm{f}(0.0-0.063) & \ldots & 3 \%
\end{array}
$$

- Particles: $\mathrm{d}_{10}=0.3, \mathrm{~d}_{30}=2.0, \mathrm{~d}_{60}=9.0, \mathrm{C}_{\mathrm{U}}=27, \mathrm{C}_{\mathrm{C}}=1.65$

- Density: $\rho_{\mathrm{d}, \min .}=1.669 \mathrm{~kg} \cdot \mathrm{m}^{-3}, \rho_{\mathrm{d}, \text { max. }}=2.208 \mathrm{~kg} \cdot \mathrm{m}^{-3}$ 
Tested geosynthetics are listed in Table 1.

Table 1: Tested geosynthetics

\begin{tabular}{|c|c|c|c|}
\hline Symbol & Name of geosynthetics & Producer & Type of geosynthetics \\
\hline A & Armatex G PET (+PVC) 55/55 & Kordárna & woven geogrid (flexible) \\
\hline $\mathrm{F}$ & Fornit (PP) 40/40-35 T & Huesker & woven geogrid (flexible) \\
\hline $\mathrm{G}$ & Geolon PP 60 & Nicolon & woven geotextile \\
\hline $\mathrm{P}$ & Polyfelt TS 700 & Polyfelt & $\begin{array}{c}\text { non-woven geotextile } \\
\text { mechanically and heat-solidified }\end{array}$ \\
\hline$S$ & Secugrid 60/60 (PET) & $\begin{array}{c}\text { Naue } \\
\text { Fasertechnic }\end{array}$ & geogrid (welded strips) \\
\hline T30 & Tensar SS30 & \multirow{2}{*}{$\begin{array}{c}\text { Tensar } \\
\text { International }\end{array}$} & extruded geogrid (rigid) \\
\hline $\mathrm{T} 40$ & Tensar SS40 & & extruded geogrid (rigid) \\
\hline
\end{tabular}

Composition of tests through the five testing series is displayed in Table 2.

Table 2: Composition of tests through the five testing series

\begin{tabular}{|c|c|c|c|}
\hline $\begin{array}{l}\text { Testing } \\
\text { series }\end{array}$ & $\begin{array}{l}\text { Average subgrade modulus } \\
\qquad E_{\mathrm{v} 2}(\mathrm{MPa})\end{array}$ & $\begin{array}{l}\text { Subbase layers thickness } \\
1^{\text {st }}+2^{\text {nd }}=\text { total }(\mathrm{cm})\end{array}$ & $\begin{array}{l}\text { Tested geosynthetics } \\
\text { (see symbol in Table 1) }\end{array}$ \\
\hline $1^{\mathrm{st}}$ & \multirow[t]{2}{*}{ 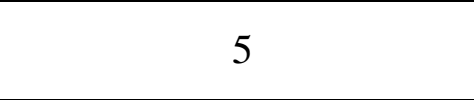 } & $20+20=40$ & $\mathrm{G}+\mathrm{T} 30$ \\
\hline $2^{\text {nd }}$ & & $15+15=30$ & $\mathrm{~S}+\mathrm{P}$ \\
\hline $3^{\text {rd }}$ & \multirow{3}{*}{15} & \multirow{3}{*}{$20+10=30$} & $\mathrm{~F}+\mathrm{A}$ \\
\hline $4^{\text {th }}$ & & & $\mathrm{G}+\mathrm{T} 30$ \\
\hline $5^{\text {th }}$ & & & $\mathrm{T} 40+\mathrm{S}$ \\
\hline
\end{tabular}

(* As described in paragraph 2.1 one testing series consists of testing two geosynthetics and a comparison measurement on the geosynthetics-free testing space.

\subsection{Results}

Table 3: Test results of static tests

\begin{tabular}{|c|c|c|c|c|c|c|c|}
\hline \multirow{3}{*}{$\begin{array}{l}\text { Testing } \\
\text { series }\end{array}$} & \multirow{3}{*}{$\begin{array}{l}\text { Subgrade } \\
\text { deformatio } \\
\mathrm{n} \text { modulus } \\
\mathrm{E}_{\mathrm{v} 2}(\mathrm{MPa})\end{array}$} & \multirow{3}{*}{$\begin{array}{l}\text { Testing } \\
\text { space } \\
\text { of } \\
\text { GLTF }\end{array}$} & \multirow{3}{*}{$\begin{array}{l}\text { Symbol of tested } \\
\text { geosynthetics } \\
\text { (see to Table 1) }\end{array}$} & \multicolumn{4}{|c|}{ Subbase } \\
\hline & & & & \multicolumn{2}{|c|}{$1^{\text {st }}$ layer } & \multicolumn{2}{|c|}{$1^{\text {st }}+2^{\text {nd }}$ layer } \\
\hline & & & & $\begin{array}{c}\text { thickness } \\
\text { (cm) }\end{array}$ & $\begin{array}{c}E_{\mathrm{v} 2} \\
(\mathrm{MPa})\end{array}$ & $\begin{array}{l}\text { thickness } \\
(\mathrm{cm})\end{array}$ & $\begin{array}{c}E_{\mathrm{v} 2} \\
(\mathrm{MPa})\end{array}$ \\
\hline \multirow{3}{*}{$1^{\mathrm{st}}$} & \multirow{3}{*}{5} & $\mathrm{I}$ & Geosynthetics-free & \multirow{3}{*}{20} & 17.90 & \multirow{3}{*}{40} & 53.66 \\
\hline & & II & $\mathrm{G}$ & & 23.23 & & 56.51 \\
\hline & & III & T30 & & 24.90 & & 55.41 \\
\hline \multirow{3}{*}{$2^{\text {nd }}$} & \multirow{3}{*}{5} & I & S & \multirow{3}{*}{15} & 11.30 & \multirow{3}{*}{30} & 22.06 \\
\hline & & $\mathrm{II}$ & $\mathrm{P}$ & & 9.94 & & 17.43 \\
\hline & & III & Geosynthetics-free & & 10.11 & & 18.18 \\
\hline \multirow{3}{*}{$3^{\text {rd }}$} & \multirow{3}{*}{15} & $\mathrm{I}$ & $\mathrm{F}$ & \multirow{3}{*}{20} & 27.18 & \multirow{3}{*}{30} & 34.82 \\
\hline & & II & $\bar{A}$ & & 29.79 & & 37.06 \\
\hline & & III & Geosynthetics-free & & 28.43 & & 38.53 \\
\hline \multirow{3}{*}{$4^{\text {th }}$} & \multirow{3}{*}{15} & $\mathrm{I}$ & $\mathrm{G}$ & \multirow{3}{*}{20} & 25.17 & \multirow{3}{*}{30} & 33.28 \\
\hline & & II & T30 & & 29.79 & & 34.86 \\
\hline & & III & Geosynthetics-free & & 28.43 & & 34.20 \\
\hline \multirow{3}{*}{$5^{\text {th }}$} & \multirow{3}{*}{15} & $\mathrm{I}$ & $\mathrm{T} 40$ & \multirow{3}{*}{20} & 25.94 & \multirow{3}{*}{30} & 35.19 \\
\hline & & II & $\mathrm{S}$ & & 27.87 & & 35.54 \\
\hline & & III & Geosynthetics-free & & 29.26 & & 37.74 \\
\hline
\end{tabular}


The pre-described values of subgrade deformation modulus $5 \mathrm{MPa}$ and $15 \mathrm{MPa}$ for the $1^{\text {st }}$ and $2^{\text {nd }}$ testing series and for $3^{\text {rd }}, 4^{\text {th }}$ and $5^{\text {th }}$ testing series respectively were achieved with difficulties by water content changing in the subsoil. The modulus was measured three times in each testing space. Values $5 \mathrm{MPa}$ and $15 \mathrm{MPa}$ are rounded off from the average value (e.g., the minimum value was $5.75 \mathrm{MPa}$ and the minimal value was $4.37 \mathrm{MPa}$ in the first series).

The first subbase layer was spread just after subgrade modulus measurement due to the subsoil drying up. Subbase modulus of deformation was measured again three times in each testing space. Values in Table 3 are the average values of the deformation modulus in each testing space.
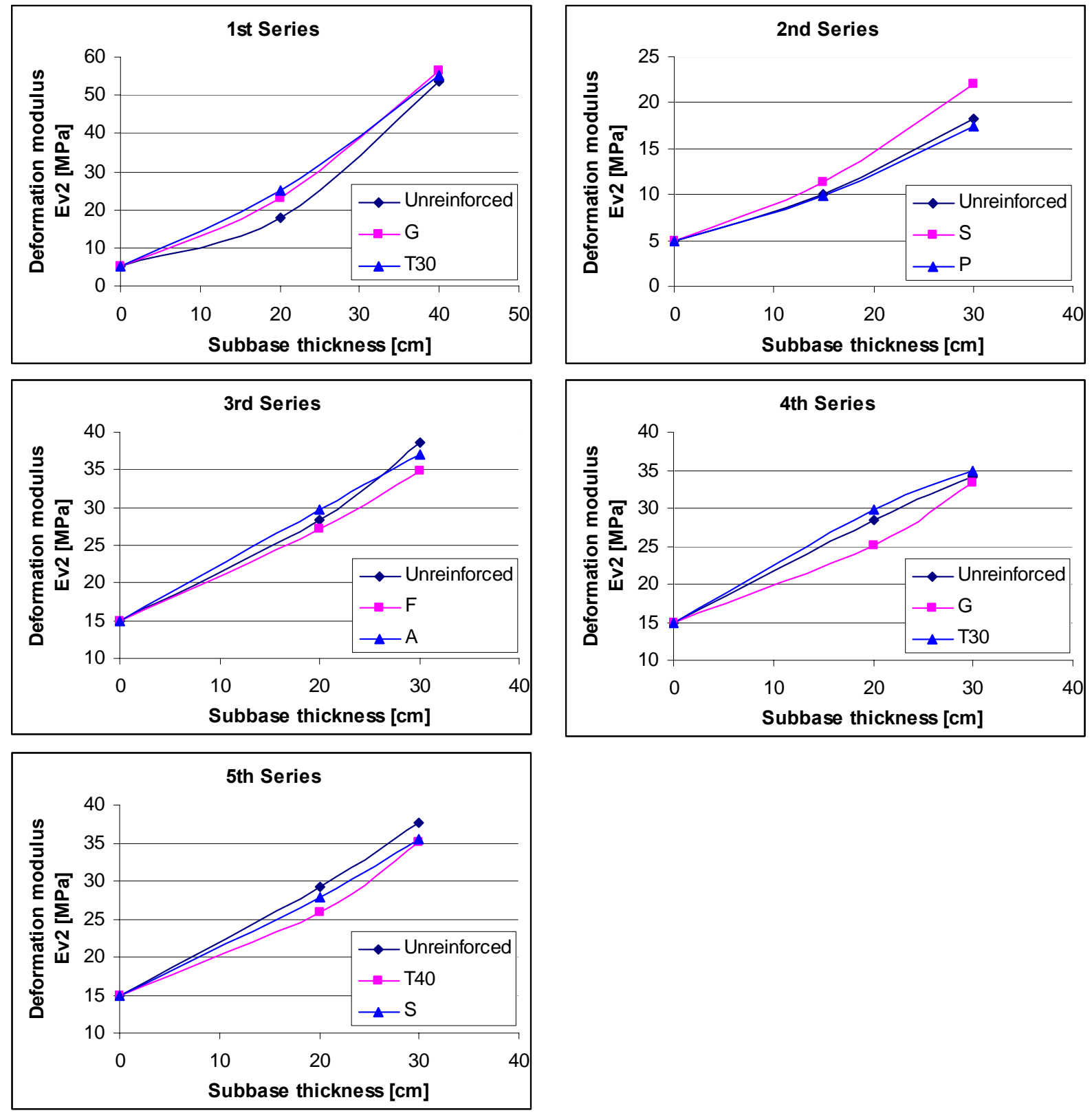

Figure 3: Results of static tests

The test results of the five testing series are concentrated in both Table 3 and Figure 3. At this point it is necessary to highlight again that the thicknesses of the subbase layers vary from series to series. They are $20 \mathrm{~cm}$ for both $1^{\text {st }}$ and $2^{\text {nd }}$ subbase layers in case of the $1^{\text {st }}$ testing 
series, $15 \mathrm{~cm}$ in case of $2^{\text {nd }}$ testing series and in case of $3^{\text {rd }}, 4^{\text {th }}$ and $5^{\text {th }}$ series the $1^{\text {st }}$ subbase layer was $20 \mathrm{~cm}$ and $2^{\text {nd }}$ layer was $10 \mathrm{~cm}$ (compare with Table 2).

While the subgrade values $5 \mathrm{MPa}$ and $15 \mathrm{MPa}$ had been chosen as representatives of very weak and weak subgrades before measurement, the subbase thicknesses were adjusted during the measurement to ensure the best geosynthetics effect on the bearing capacity.

\subsection{Discussion on static tests results}

As demonstrated in Table 3 the bearing capacity increase due to geosynthetics usage is significant on the first $15 \mathrm{~cm}$ subbase layer spread on geosynthetics laid on the very weak subgrade of $5 \mathrm{MPa}$ deformation modulus only (see $1^{\text {st }}$ series and $1^{\text {st }}$ subbase layer measurement). Partly the same effect is visible in the $2^{\text {nd }}$ series (geosynthetics " $S$ " vs. geosynthetics-free testing space).

The other testing series did not demonstrate any effects of geosynthetics on the bearing capacity increase. The test results of these measurements are the same (geosynthetics used or unused) within the frame of statistical discrepancies.

On the other hand, the explanation of geosynthetics behaviour as a tool of bearing capacity increase is based on the static plate test only. This presumption is fully causative, because the plate static test is widely used for the evaluation of newly-built subgrade in many European countries (Germany, Austria, Czech Republic, Slovakia, etc.). However, this test cannot take into account future construction behaviour, which seems to be very important in the case of geosynthetics, whose incidence could increase through the exploitation time in a construction. Therefore, testing under cyclic loading was arranged.

\section{ENVIRONMENT, PARAMETERS AND RESULTS OF TESTS UNDER CYCLIC LOADING}

Considering the results of the static tests it was decided to continue with the observation of geosynthetics behaviour under cyclic (dynamic) loading. With respect to the GLTF parameters, cyclic loading via a circular plate with a diameter of $30 \mathrm{~cm}$ (the same as for the static plate test) was chosen. For this purpose, it was necessary to design, fabricate and open a new facility - the PneuTester. Analogous facilities were used by Penner, 1985 and Perkins, 2002.

\subsection{Facility}

The facility for cyclic testing (except the GLTF, see Chapter 2) consists of:

1. Pneumatic loading system (PneuTester, see Figure 4):

- source of compressed air - compressor Schneider 850-270 ST

- compressed air set-up unit FRC-1/2-D

- pneumatic piston chamber DNG 250

- proportional reducer, pass valve, small items (silencers, connecting hoses, etc.)

2. Computer based electronic measuring and control system with soil and geosynthetics stress gauges, strain indicators, software. 
The PneuTester facility is displayed in Figure 4.
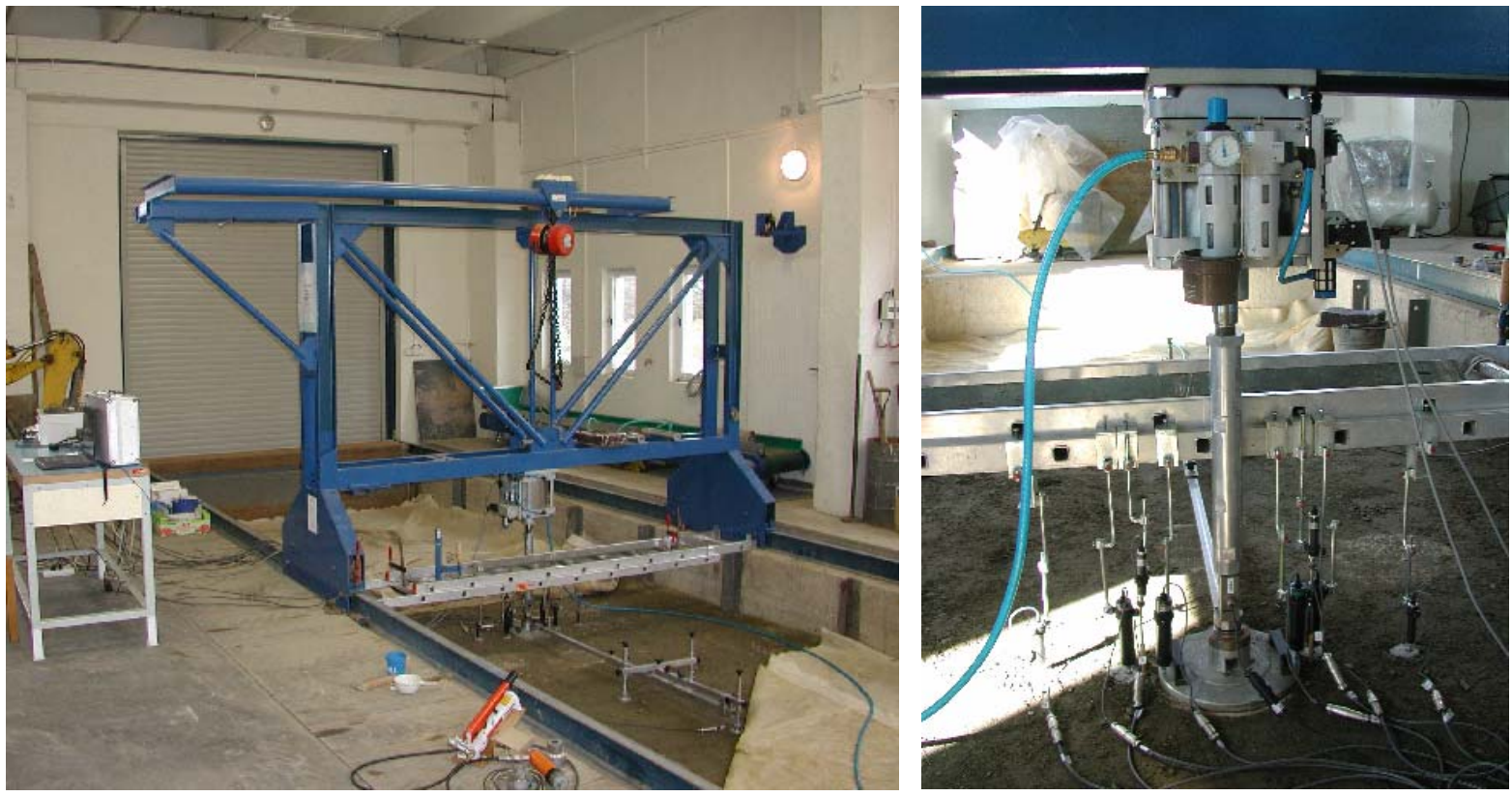

Figure 4: The PneuTester in the GLTF

\subsection{Tests arrangement}

The research plan was composed as described hereinafter and the tests and their methodology are still in progress. The GLTF was divided into three testing spaces of the same size ( $3 \mathrm{~m} \times$ $3 \mathrm{~m}$ ) again. It is supposed that ten series of tests will be carried out on subgrade with deformation modulus $\mathrm{E}_{\mathrm{v} 2}=5 \mathrm{MPa}$ and $15 \mathrm{MPa}$ as within the static tests. Up to now, two testing series have been carried out (the meaning of a testing series is the same as described in Chapter 2).

As in the case of the static tests, the subsoil was spread and compacted into GLTF layer by layer, up to the final thickness of $70 \mathrm{~cm}$. The material of the subsoil layers was the same as described in Chapter 2.2.

The individual series of testing varies in the types of geosynthetics used. The thicknesses of subbase layers are (will be) the same in all series $20 \mathrm{~cm}-1^{\text {st }}$ layer and $10 \mathrm{~cm}-2^{\text {nd }}$ layer, i.e., $30 \mathrm{~cm}$ total thickness of the subbase layer.

Parameters of the cyclic loading was determined with respect to the similarities to real traffic loading: stress under the loading plate $-0.4 \mathrm{MPa}$, loading frequency $-0.5 \mathrm{~Hz}$, number of cycles - min. 100000 (informatively in some cases 500000 and 1 mil.).

\subsection{Measured quantities}

Within the tests the following quantities were measured:

1. Modulus of deformation $E_{\mathrm{v} 2}$ - before and after cyclic loading

2. E-modulus - continuously during the tests

3. Contact stress and deformation - continuously during the tests

4. Tensile stress of geosynthetics - continuously during the tests

5. Stress on subgrade level under the plate centre

6. Deformation on subgrade level under the plate edge (2 sensors)

7. Deformation at the top of subbase layer in horizontal distances of $20 \mathrm{~cm}, 40 \mathrm{~cm}$ and $60 \mathrm{~cm}$ (from the plate centre)

8. Air temperature and temperature of the sensor support 


\subsection{Results}

The basic outputs are in the form of graphic relationships between the deformation under the plate and the number of loading cycles. A summary of the test results is shown in Figure 6. As the purpose of our paper is not to evaluate the influence of geosynthetics of selected producers, we do not specify which curve in the graph of Figure 6 relates to specific geosynthetics. The graph should be understood as a demonstration of the selected geosynthetics influence on the deformation of the subbase made on soft subgrade. It could also be stated that the geosynthetics-less testing space demonstrated a deformation of up to $3 \mathrm{~mm}$ as is visible in the graph. If we take in to account this finding, it is possible to say that the majority of geosynthetics increases deformations of the subbase made on soft-soil.

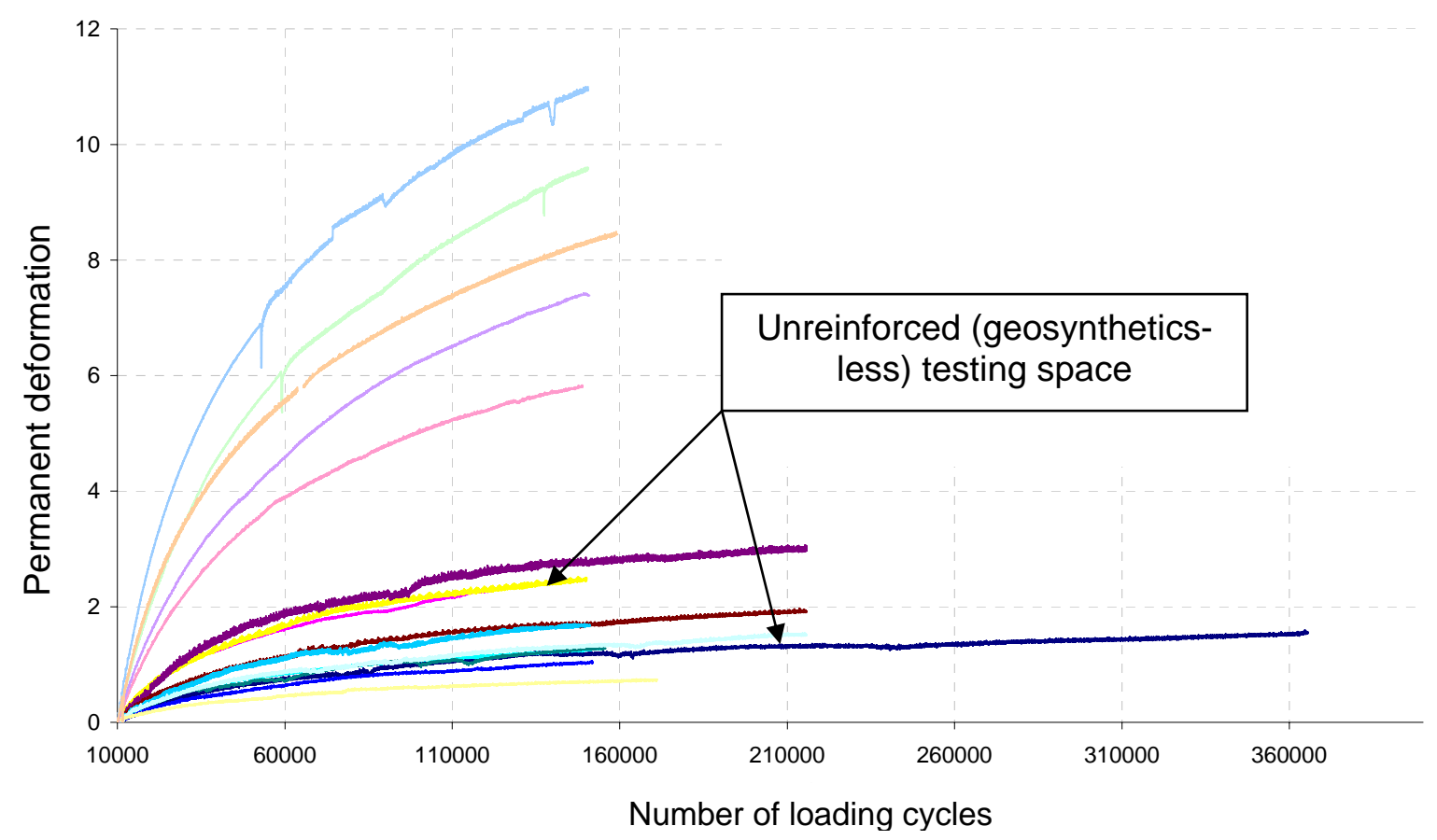

Figure 6: Dependence of subbase deformation reinforced by selected geosynthetics on a number of cycles - unreinforced subbase showed deformation up to $3 \mathbf{~ m m}$

The tests summarised in Figure 6 were carried out on the $1^{\text {st }}$ subbase layer (i.e., $20 \mathrm{~cm}$ thick - see Figure 2). Deformation moduli of the subbase in all cases were before tests $(27 \pm 3) \mathrm{MPa}$ and $(53 \pm 3) \mathrm{MPa}$ after tests (after loading). Tensile stress of geosynthetics caused by cyclic loading was not observed.

\subsection{Discussion on tests under cyclic loading}

As demonstrated in Figure 6 it was found that a reinforced subbase had, in the majority of cases, a higher deformation within loading than unreinforced subbase. This, perhaps, unexpected result, shown exemplarily in Figure 6, was validated through additional experiments with very similar results.

The two curves in Figure 6 assigned to the unreinforced subbase (representing repetitive two tests) show that geosynthetics-less formation has more or less the same deformation as reinforced formation uses the "best" geosynthetics. Using this finding it is possible 
to formulate the following: Geosynthetics spread on weak soft soil have an indifferent or worsening influence on subbase deformation and deformation modulus.

\section{CONCLUSION}

Full-scale tests are preferred for their predicative ability, as they are not affected by model testing inaccuracy. Their results are useful for back-calculation when defining calculation processes and for designing constructions.

The results of the static tests demonstrated the unbeneficial influence of selected geosynthetics on increasing bearing capacity. To this conclusion there were opponent statements expressed during the scientific conferences (e.g., $7^{\text {th }}$ International Conference on Geosynthetics in Nice, 2002, and BCRA conference in Trondheim, 2005).

According to the opponents, the influence of geosynthetics increases with their exploitation. They presume that traffic loading causes toothing aggregate in to geogrids and by this effect geogrids are able to mediate tensile stress. It can be stated that perhaps in the case of some geosynthetics described effect causes a slightly lower deformation of the subbase surface after the loading tests, in comparison with unreinforced soil, even if the tensile stress of the geosynthetics was not detected. We do not understand this lower deformation as an influence of the geosynthetics but a random event caused within the frame of accuracy of the testing method. The influence of the "toothing effect" on the bearing capacity expressed by the deformation modulus measured after the tests has not been observed.

The very speculative benefits in the case of the reinforced subbase pavement layers on weak subgrade, affected by static and cyclic loading tests can be summarized as follows:

- The only significant benefit of geosynthetics usage was demonstrated in the case of the static tests on subgrade with Ev2 $=5 \mathrm{MPa}$ observed on subbase layers of up to $30 \mathrm{~cm}$ thick.

- Some of tested geosynthetics shoved out a slight but measurable influence on the final permanent deformation of subbase surface. We do not understand this positive influence as authenticated.

The final conclusion of our findings can be expressed in two topics with respect to the selected geosynthetics, the tests arrangements and real usage (if similar with tests carried out):

- Geosynthetics usage for increasing bearing capacity is not reasonable.

- Geosynthetics usage for deformation decreasing was not authenticated. In the majority of observed cases a worsening influence of geosynthetics was demonstrated. (This conclusion does not concern the usage in the case of unpaved roads where geosynthetics protect from creating deep ruts due to their "membrane effect".

- The behaviour of geosynthetics in observed formations can be understood as a separation layer which causes the sliding of the upper layer on the geosynthetic surface. Subsoil does not work as a formation but as several separated layers which has worse deformation characteristics as a whole collaborating formation.

It should be expressed that our findings do not generally concern all products, as well as other geosynthetics features, i.e., separation, filtration, protecting, slope/embankment-reinforcing, etc., where geosynthetics often play an unsubstitutable role.

The results of the described research are too comprehensive to be published as a journal paper in full text. Therefore the authors are preparing a monograph consisting of all the findings and descriptions. 


\section{ACKNOWLEDGEMENT}

This research was supported with grants from the Ministry Transport of the Czech Republic, No.1F45B/02/120 and MD0-44994575.

\section{REFERENCES}

Beckmann, U., Ruppert, 1994. Anwendung von Tensar Geogittern im Straßenbau. BRP Consult, Braunschweig, Germany.

Berg, R.R. at al., 2000. Geosynthetic Reinforcement of the Aggregate Base//Subbase Courses of Pavement Structures. GMA White Paper (Report for AASHTO Committee 4E), USA.

Blumme, K. at al., 2001. Erhöhung der Tragfähigkeit ungebundener Tragschichten über nicht ausreichend tragfähigem Erdplanum durch Bewehrungslagen aus Geokunststoffen. Abschlussbericht FE-Nr. 05.105G951, Universität Stuttgart, Germany.

Jenner, C.G., Watts, G.R.A., Blackman, D.I., 2002. Trafficking of Reinforced, Unpaved Subbases over a Controlled Subgrade. In Proceedings, 7th International Conference on Geosynthetics, pp.897-904, Nice, France.

Penner, R., Haas, R., Walls, J., Kennepohl, G., 1985. Geogrid Reinforcement of Granular Bases. Roads and Transportation Association of Canada Annual Conference, Vancouver, Canada.

Perkins, S. W., 2002. Evaluation of Geosynthetic Reinforcement Flexible Pavements Systems Using Two Pavement Test Facilities. FHWA/MT - 02-008/20040, Montana State University, USA.

Perkins, S. W., 2001. Mechanistic-empirical Modeling and Design Model Development of Geosynthetic Reinforced Flexible Pavement. FHWA/MT - 01-002/99160-1A, Montana State University, USA.

Pospisil, K., Zednik, P., 2002. Geosynthetics Impact Recognition on Soil Bearing Capacity in the Geotechnical Laboratory Testing Field. In Proceedings, 7th International Conference on Geosynthetics, pp.419-422, Nice, France.

Saathoff, F. , Horstmann, J., 1999. Geogitter als Bewehrung in ungebundenen mineralischen Schichten, Strassen- und Tiefbau, Heft 5, S.16-20, Germany.

van Niekerk, A.A., van Gurp, C.A.P.M., 2002 Analysis of Trafficking Trial Data for Sub-base Reinforcement According to the CROW-157 Design Approach. (Trafficking Trials Carried out at TRL), Final Report (e0200262), KOAC WMD, The Netherlands.

Watn, A., Sognen, H., Emdal, A., 1996. Improvement of Bearing Capacity for Traffic Areas on Soft Subsoil: Large-scale Laboratory Testing. Geosynthetics: Applications, Design and Construction, Rotterdam, The Netherlands. 